\title{
Harmonizing Eating and Exercise Circadian Rhythms for Optimal Glucose-Insulin and Vascular Physiology
}

Akbar Nikkhah

Chief Highly Distinguished Professor, Department of Animal Sciences, Faculty of Agricultural Sciences, University of Zanjan, National Elite Foundation, Iran.

\begin{abstract}
This article establishes a global but individual public program based on rhythmic circadian eating and exercise extent and rate to harmonize intermediary metabolism. This will help optimize glucose assimilation and insulin dynamics towards healthier heart and vascular functions. Any and every circadian meal must have its matching physical activity to optimize substrate oxidation and waste management.
\end{abstract}

Keywords: Harmony; Eating Time; Exercise; Circadian Rhythms; Vascular System.

\section{*Corresponding Author:}

Akbar Nikkhah,

Chief Highly Distinguished Professor, Department of Animal Sciences, Faculty of Agricultural Sciences, University of Zanjan, National Elite Foundation, Iran.

Tel: +919953658829

E-mail: anikkha@yahoo.com nikkhah@znu.ac.ir

Recieved: March 07, 2015

Accepted: April 02, 2015

Published: April 07, 2015

Citation: Akbar Nikkhah (2015) Harmonizing Eating and Exercise Circadian Rhythms for Optimal Glucose-Insulin and Vascular Physiology. Int J Diabetol Vasc Dis Res, 3(3) 87-88. doi: http://dx.doi. org/10.19070/2328-353X-1500017

Copyright: Akbar Nikkhah ${ }^{\odot} 2015$. This is an open-access article distributed under the terms of the Creative Commons Attribution License, which permits unrestricted use, distribution and reproduction in any medium, provided the original author and source are credited.

\section{Introduction}

The objective of this perspective article was to describe a harmony between eating and exercise circadian rhythms in establishing healthy cell metabolism and waste management. This establishment should permit a more functional and healthier vascular physiology. The philosophy gains support from the implications of the most recent discoveries on circadian timing of nutrient intake [1-3].

\section{Discoveries and Discussion}

Ruminant animal models studies suggest that taking the same diet in morning vs. evening has different intake behaviour and metabolic consequences $[4,5]$. As a result, nutrient output in terms of meat and milk depends also when during a circadian period (i.e., almost a 24-h period) food is ingested, digested, assimilated and metabolized [6]. In humans as a diurnal animal, moreover, glucose tolerance and insulin sensitivity diminish as the inactivity period or evening/nigh time begins [7-11]. As such, splanchnic and peripheral cells are not as well prepared nocturnally as they are diurnally in processing substrates towards oxidation, deposition, mobilization, secretion and excretion [12,13]. Thus, any oversupply of nutrients and substrates to gastrointestinal tract, liver, and peripheral tissues overnight encounters unhealthy consequences [14]. These include uncontrolled dramatically hyperglycaemia, unregulated insulin secretion and function, futile substrate bioprocessing, deficient oxidation, and impaired waste management. Such abnormalities could predispose cells to oncogenic conditions as well [12]. Fundamentally, such food meals matched with intensive daily exercise programs could reduce the stress on cells. However, the optimum approach is to have daily physical activity and prevent such situations from happening through frequent and modest daily meals and avoiding large nocturnal meals. As a rule of thumb, any sizeable meal on a circadian basis must have its corresponding significant exercise to minimize irregularities in cell metabolism and maintenance. Therefore, no single public global guideline may be formulated for effective use and effect by all. Instead, different groups and individuals with varying nutritional regimens and behaviour will require matching exercise programs to harmonize cellular substrate input, oxidation, transformation, partitioning and wastage.

\section{Implications}

Circadian regimes for nutrient intake and exercise must precisely match to minimize risks from deficient substrate oxidation and waste mismanagement. Optimal metabolic health and functional cardiovascular dynamics demand maintaining circadian harmonies between rhythms of nutrient consumption and bioprocessing and rhythms of physical activity to help establish regularities 
in cellular biochemistry and biophysics. Such a harmony works towards prolonged quality insulin function and cardiovascular properties.

\section{Acknowledgment}

Thanks to the Ministry of Science Research and Technology, National Elite Foundation, and University of Zanjan, Iran, for supporting the author's global programs of optimizing science edification in the third millennium.

\section{References}

[1]. Nikkhah A (2013) Chronophysiology of ruminant feeding behavior and metabolism: an evolutionary review. Biol. Rhythm Res 44(2): 197-218.

[2]. Nikkhah A (2012) Time of Feeding an Evolutionary Science, Lap Lambert Publishing, GmbH \& Co. KG, Germany, ISBN 978-3-8473-3260-2.

[3]. Nikkhah A (2014) Review: Ruminant feed intake regulation evolution: Chronophysiological rhythms perspectives. Biol. Rhythm Res 45(4): 563 577.

[4]. Nikkhah A (2014) Timing of feeding: a postmodern management strategy to modulate chronophysiological rhythms in rumen fermentation kinetics. Biol Rhythm Res 45(4): 533-540.

[5]. Nikkhah A (2014) Timing of eating a global orchestrator of biological rhythms: dairy cow nitrogen metabolism and milk fatty acids. Biol. Rhythms Res 45(5): 661-670.

[6]. Nikkhah, A (2013) Time of feeding orchestrates circadian post-feeding intake rhythms in dairy cows. J. Anim. Poult. Sci 2(2): 55-60.

[7]. Nikkhah A (2014) Eating timing and diabetes. Int.J. Diabetol. Vas. Dis. Res 2: 101.

[8]. Nikkhah A (2015) Intake circadian physiology: An overlooked public health concern. Endocrinol. Metab. Synd 1:1. http://dx.doi.org/10.4172

[9]. Nikkhah A (2014) Perspective: Nutrient intake chronophysiology: A rising public health concern. J. Nutr. Therap 3(4): 156-157.

[10]. Nikkhah A (2015) Optimizing health management through circadian feed intake rhythms: A prognostic SciTech. J. Vet. Sci. Technol. 6: e115.

[11]. la Fleur SE, Kalsbeek A, Wortel J, Fekkes MI, Buijs RM (2001) A daily rhythm in glucose tolerance: a role for the suprachiasmatic nucleus. Diabetes 50: $1237-1243$

[12]. Nikkhah A (2015) Establishing rhythmic regularities in cell physiology: A novel global program to thwart cancer. J. Nutr. Health Food Eng. In Press.

[13]. Nikkhah A (2015) Wrecked oncogenesis through synchronized substrate availability and oxidation: A novel bioengineering of cell physiology. Aust. J. Biotechnol. Bioeng. In Press.

[14]. Nikkhah A (2014) When to eat to beat obesity and diabetes? J. Diabet. Metab 5:7. 